\title{
Immunological Methods in Gluten Risk Analysis: A Snapshot
}

\author{
Francesca Melini and Valentina Melini * \\ CREA Research Centre for Food and Nutrition, Via Ardeatina 546, I-00178 Roma, Italy; \\ francesca.melini@crea.gov.it \\ * Correspondence: valentina.melini@crea.gov.it; Tel.: +39-348-7291913
}

Received: 11 October 2018; Accepted: 16 November 2018; Published: 1 December 2018

check for updates

\begin{abstract}
Gluten is among the 14 major food allergens officially recognized by Regulation (EU) No. $1169 / 2011$. The risk to coeliac patients from gluten presence in the food products they consume is likely due to the unintentional contamination of naturally gluten-free (GF) and GF-labelled products, or to hidden sources of gluten in processed GF products. The aim of this paper is to provide a snapshot of gluten risk analysis, with emphasis on immunological methods currently used in gluten detection. The study highlights that immunoassays have some advantages over other analytical methods in gluten determination and are suitable for routine tests. However, some factors (e.g., complexity of the food matrix, type of the applied antibody, gluten extraction procedures and lack of reference material) affect the reliability of obtained results. Hence, efforts are required at an analytical level to overcome the drawbacks of the immunological methods currently available. Harmonization is necessary, so as to assist both consumers in making safe food choices, and the food industry in gluten risk assessment, management and communication.
\end{abstract}

Keywords: gluten risk analysis; gluten-free food safety; gluten detection; immunological methods; gluten-free product labelling

\section{Introduction}

The prevalence of food allergies is increasing, and recognition of the importance of food allergy as a public health and food safety issue has improved [1]. According to the European Academy of Allergy and Clinical Immunology (EAACI), allergy is the most common chronic disease in Europe [2]. Today, more than 150 million Europeans suffer from chronic allergic diseases and the current prediction is that the share of EU population affected by them will grow by 2025 [2]. Food allergy management hence merits prioritisation through concerted research efforts and public health programmes involving all stakeholders: consumers, scientists, health policy-makers, and legislators. Synergistic action among them is the prerequisite for any attempt to improve prevention, diagnosis and treatment.

In this framework, the implementation of risk analysis programmes has become a priority. The food industry and public health authorities have specifically developed and implemented strategies to protect the food allergic consumer.

So far, 14 major food allergens have been officially recognized by Regulation (EU) No. 1169/2011 on the provision of food information to consumers [3]. Within this overarching list of substances and/or food products causing allergies or intolerances, there are also gluten-containing cereals (i.e., wheat, rye, barley, oats, spelt, kamut or their hybridised strains, and products thereof) [3]. The ingestion of the gliadin fraction of wheat and of the prolamins of rye (secalins), barley (hordeins) and possibly oats (avidins) provokes disorders in some people.

Wheat allergy, gluten-sensitivity and coeliac disease (CD) are the three gluten-related disorders [4]. Wheat allergy is defined as an adverse type-2 helper T-cell immunologic reaction to wheat proteins [4]. 
It is immunoglobulin E (IgE) mediated. It typically presents soon after ingestion of wheat. It is especially common among children, with a reported prevalence of $2-9 \%$ in children and $0.5-3 \%$ in adults. Non-coeliac gluten sensitivity is the term used to describe the disorder that individuals have upon ingestion of gluten-containing grains, with improvement when these are removed from diet [4]. The frequency of non-celiac gluten sensitivity is claimed to be higher than $C D$, with prevalence estimates ranging from $0.6 \%$ to $6 \%$ of the population [5]. Coeliac disease is a chronic, small-intestinal immune mediated enteropathy initiated by exposure to dietary gluten in genetically predisposed individuals. It is characterized by specific antibodies against tissue transglutaminase 2 (anti-TG2), endomysium, and/or deamidated gliadin peptide. It affects one in every hundred individuals in Western population [5], who suffer from atrophy of the mucosal villi, and hence from nutrient malabsorption and malnutrition.

Over the last decades, the contamination of naturally or labelled gluten-free (GF) products has been investigated [6-8]. An agreement has been reached on the importance of risk analysis and identification of the most useful and high-throughput tools, efficiently supporting scientist efforts and public health programmes.

The aim of this paper is to provide a snapshot of the role played by immunological methods in the framework of surveillance and monitoring of safety of GF products, with emphasis on their current requirements and challenges. The paper thus introduces the legislation and standards currently on force for GF food products. It then presents the main health risks caused by the cross-contamination of GF food products, and subsequently analyses the different strategies implemented by the food industry: Good Manufacturing Practices (GMPs) and Hazard Analysis and Critical Control Points (HACCP). The focus is on the analysis of analytical techniques currently used to trace gluten, and on the speculation about their role in gluten risk management and contribution to amend legislation about GF labelling. A discussion on the requirements and challenges of analytical methods is provided, so as to understand which are the efforts to implement in gluten risk management practices.

\section{Materials and Methods}

\section{Literature Search and Including/Excluding Criteria}

The study layout was first designed by the authors, and a literature search for papers on planned topics was conducted on SCOPUS in order to identify the literature relevant to the topic.

Combinations of terms related to analytical methods for gluten tracing were cross-used: coeliac disease (or "celiac disease"), gluten risk analysis, gluten risk management, gluten detection, gluten tracing, ELISA, immunological methods/assays, gluten-free food labelling, good manufacturing practices, HACCP.

In order to obtain only very up-to-date literature, papers published before 2013 were first excluded. The authors decided, nevertheless, to include earlier references when their contribution to the general workflow was of use.

Reference lists of articles were also scanned to further identify relevant papers that were not found in the original search through electronic databases. Duplicate papers and articles not accessible for authors were not included. Screening of the full text resulted in a further exclusion of papers.

The websites of worldwide Regulatory bodies were also consulted for standards and regulations: Codex Alimentarius International Food Standards [9], Official Journal of the European Union [10], U.S. Food and Drug Administration [11], Health Canada [12], Food Standards Australia and New Zealand [13], European Academy of Allergy and Clinical Immunology [2], to retrieve the on-force legislation and/or standards regarding labelling of gluten-free food products or gluten risk analysis.

Here below the PRISMA containing the paper search and selection process which this review is based on (Figure 1). 

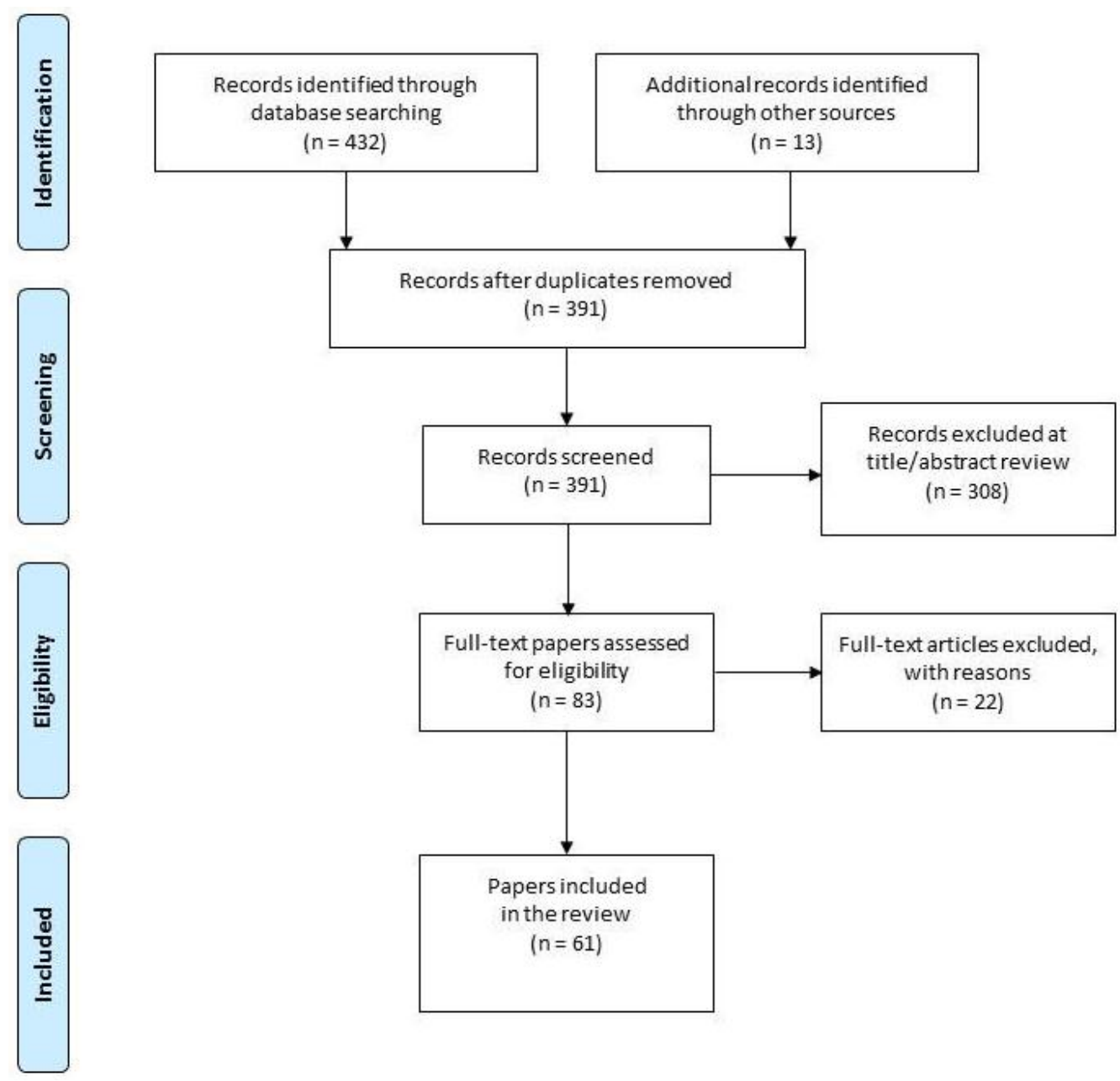

Figure 1. PRISMA statement.

\section{Results}

\subsection{Gluten Risk Assessment}

Thus far, no treatment is available for CD, except a lifelong exclusion of gluten from the diet. The adherence to a gluten-free diet (GFD) hence remains an essential condition to have remission of symptoms, normalisation of serum antibodies and intestinal mucosal recovery.

Recently, Galli and colleagues (2014) [14] investigated the effect of GFD adherence on histological recovery in a prospective one-year follow-up study of adult patients with $C D$, and found that $66 \%$ of subjects with adherence to GFD showed complete histological recovery $(p<0.00001)$, while no patient with inadequate adherence achieved it. The adherence to GFD also enables preventing CD complications, such as anemia, osteoporosis fractures and small-bowel lymphoma [15].

However, intentional and unintentional ingestion of gluten by coeliac patients may occur. Dietary transgression is commonly observed among CD subjects. The compliance with GFD is in fact difficult, both in children and adults, because GF products have low palatability and high costs. Social and practical pressures also limit a strict compliance with GFD.

Alongside intentional consumption of products containing gluten, unintentional ingestion of small amounts of the allergen may also occur in patients adherent to GFD. Now, there is the risk to coeliac subjects from gluten presence in the products they consume, which may come from the contamination of GF products (usually pre-packed or prepared from GF cereals), naturally GF products (e.g., fruits and vegetables, legumes, meat, fish, eggs, and dairy products), or from processed products with hidden sources of gluten. 
GF cereals may undergo a cross-contamination with gluten-containing grains (e.g., wheat, rye, barley, oats, spelt, kamut) along the production chain, that is, during harvest, storage, milling, transportation and/or processing. For most naturally GF foods, the chance of cross-contamination with gluten is low, provided that they are not processed. Cross-contamination may in fact occur during the production of GF products or the preparation of GF meals. Moreover, there is risk of hidden sources of gluten. Due to its technological properties, especially the high visco-elasticity, gluten is, in fact, used extensively by the food industry as a flavour enhancer, thickener, emulsifier, filler and fortifier, and might be hidden in names such as "flavourings", or "hydrolysed vegetable proteins".

\subsection{Threshold Values Currently On-Force for Gluten-Free Food Products}

According to Revision 2008 of Standard 118-1979 for Foods for Special Dietary Use for Persons Intolerant to Gluten, GF foods are defined as:

(a) foods consisting of or made only from ingredients which do not contain any prolamins from wheat, durum wheat, rye, barley, oats, or any Triticum species, such as spelt (Triticum spelta L.), , kamut (Triticum polonicum L.), or their crossbred varieties with a gluten level not exceeding $20 \mathrm{mg} / \mathrm{kg}$ in total, based on the foods ready for consumption [9]; or

(b) foods consisting of ingredients from wheat, rye, barley, oats, or any Triticum species, such as spelt (Triticum spelta L.), kamut (Triticum polonicum L.), or their crossbred varieties, which have been rendered "gluten-free", with a gluten level not exceeding $100 \mathrm{mg} / \mathrm{kg}$ in total, based on the foods ready for consumption [9]; or

(c) any mixture of the two ingredients as in a) and b) with a gluten level not exceeding $100 \mathrm{mg} / \mathrm{kg}$ in total, based on the foods ready for consumption [9].

Within Europe, the currently applying definitions, thresholds and labelling rules match those laid down by the 2008 Revision of Standard 118-1979. Up to 20 July 2016, the definition of GF products and the recommended limits of the Codex Alimentarius standard were implemented in Commission Regulation No. 41/2009 [16], which has been nevertheless repealed after that date by Regulation (EU) No. 609/2013 on food intended for infants and young children, food for special medical purposes, and total diet replacement for weight control [17]. The Commission also transferred the rules of the Regulation (EU) No. 41/2009 under the framework of Regulation (EU) No. 1169/2011 on the provision of food information to consumers, which currently lays down rules about the mandatory labelling for all foods of ingredients, among which gluten-containing ingredients with a scientifically proven allergenic or intolerance effect [3]. In order to ensure clarity and consistency, it is considered the framework for the rules related to information on the absence of gluten in food.

More recently, Commission Implementing Regulation (EU) No. 828/2014 has also entered into application, and it specifically lays down requirements for the provision of information to consumers on the absence or reduced presence of gluten in food [18]. In detail, the Regulation sets out the conditions under which foods may be labelled as "gluten-free" or "very-low gluten". The statement "gluten-free" may only be made where the food, as sold to the final consumer, contains no more than $20 \mathrm{mg} / \mathrm{kg}$ (ppm) of gluten. The statement "very low gluten" may only be made where the food, consisting of or containing one or more ingredients made from wheat, rye, barley, oats or their crossbred varieties which have been specially processed to reduce the gluten content, contains no more than $100 \mathrm{mg} / \mathrm{kg}$ (ppm) of gluten in the food, as sold to the final consumer. In both Regulation (EU) No. $1169 / 2011$ and Regulation (EU) No. 828/2014, a specific mention for food containing oats is also made.

In the United States of America and Canada, the same threshold value of $20 \mathrm{ppm}$ is set for products with a GF label. On 5 August 2013, the U.S. Food and Drug Administration (FDA) issued a rule defining the term "gluten-free" for voluntary use in food labeling [11], and the compliance date for the final rule was 5 August 2014. The rule was issued under the Food Allergen Labelling and Consumer Protection Act of 2004 as amendment to part 101 of Title 21 of the Code of Federal Regulations. In addition, the FDA issued a guide for small food businesses to help them comply 
with the final rule's requirements on June 25, 2014 [11]. Contrary to the European legislation, the GF label may be applied to any food that does not contain a gluten-containing grain, naturally GF foods inclusive, as long as its gluten content does not exceed $20 \mathrm{ppm}$, which is the lowest level that can be reliably detected in foods using scientifically validated analytical methods. Besides the limit of gluten to $20 \mathrm{ppm}$, the rule permits labelling a food "gluten-free", if the food does not contain: (i) an ingredient that is any type of wheat, rye, barley, or crossbreeds of these grains; (ii) an ingredient derived from these grains that has not been processed to remove gluten, or; (iii) an ingredient derived from these grains that has been processed to remove gluten, but results in the food containing more than $20 \mathrm{ppm}$ of gluten.

In Canada, in order for a food to be represented as "gluten-free", it must comply with section B.24.018 of Section on "Foods for Special Dietary Use" (Division 24) of the Food and Drug Regulations-C.R.C., c. 870 [12]. Claims to the effect that a food does not contain an ingredient or substance must be factual and not misleading. The rule thus reads that it is prohibited to label, package, sell or advertise a food in a manner likely to create an impression that it is a GF food, if the food contains any gluten protein or modified gluten protein, including any gluten protein fraction from wheat, oats, barley, rye, triticale or their hybridized strains. The rule does not lay down any specific threshold for gluten in products represented as "gluten-free". However, Health Canada considers that levels of gluten protein below $20 \mathrm{ppm}$ generally do not represent health risks to consumers with CD. The Canadian Food Inspection Agency (CFIA) has published a position on the Compliance and Enforcement of Gluten-Free Claims [19] that reflects the Health Canada position, and takes into account whether gluten is present due to intentional addition or to cross-contamination. As to oats, a marketing authorization was registered on 19 May 2015, permitting the use of the "gluten-free" claim for GF oat product, specially produced and not containing more than $20 \mathrm{ppm}$ of gluten from wheat, barley and rye [12].

In Australia, the sensitivity of testing is now able to detect as little as 3 ppm gluten (type I method R5), which means any food, labelled "gluten-free", has to be under that limit to be considered gluten-free. Specifically, the new Standard 5.1.1., which entered into force on 1 March 2016, repealing Standards 1.2.7 on "Nutrition, Health and Related Claims" and Standard 2.9.5. on "Food for Special Medical Purposes", is based on a "no-detectable" non-fixed gluten limit, as opposed to the fixed value adopted in Europe and the USA defined as no more than 20 ppm of gluten [13]. Law limits/threshold values are by far established on the basis of the sensitivity of analytical methods.

\subsection{Gluten Risk Management}

As people who are gluten-intolerant and/or have CD suffer from intestinal pain and associated complications if they eat food that is not gluten-free, food manufacturers and processors that label their products "gluten-free" have a responsibility to ensure that they use this claim in a truthful manner, so that they do not mislead the consumer.

Gluten risk management is an integral part of the existing safety systems implemented by the food industry. To that aim, the food industry, which is involved at the forefront, must establish a system compliant with the principles of GMPs and HACCP, and must apply reliable and robust analytical methods to check and ensure the safety of GF labelled foods.

This combination can help, in fact, manufacturers of GF products to develop an "allergen" process flow that identifies the allergenic ingredients and foods within a facility, including the specific points where they are introduced into the process. The flow is translated into an allergen management plan that minimizes the risk of cross-contamination during production, and ensures continuous compliance with the principles of food safety. 
3.3.1. Good Agricultural Practices, Good Manufacturing Practices and Hazard Analysis an d Critical Control Point

Good Agricultural Practices (GAPs), Good Manufacturing Practices and Hazard Analysis and Critical Control Point are among the strategies enabling the safety of GF products.

GAPs are applied to avoid adventitious GF cereal cross contamination with gluten-containing cereals, that is likely under normal operating conditions, such as harvest and post-harvest. It is nevertheless worth mentioning the risk of contamination when tons of grains are handled.

GMPs apply at a later stage, in food manufacturing. Employees, suppliers, raw material handling, design of equipment and facilities, and product manufacturing are the targets. Generally speaking, in food allergen management, GMPs aim to avoid cross contact: (i) by training and creating awareness of allergen risk among employees; (ii) by obtaining and verifying information about the allergen status of the raw materials and ingredients; (iii) by minimizing cross-contact among the incoming raw materials and ingredients; (iv) by monitoring equipment design; $\mathrm{v}$ ) by cleaning steps and (vi) by implementing segregation, that is, separate utensils, line dedication, equipment and storage dedication.

A HACCP System is also implemented, which includes, in the case of gluten risk management, the assessment of hazard at all stages of production, storage, transportation and handling, to ensure the avoidance of gluten contamination and subsequent management.

The last version of the Standard for Gluten-Free Foods, which was released by the Association of European Coeliac Societies (AOECS) in September 2016 and lays down technical requirements for licensing the Crossed Grain Symbol, provides a specific HACCP Guidance for managing GF production [20]. In detail, it identifies the process phases and the related hazard, and also provides recommendations for prevention and correction of hazards [20]. For example, suppliers must be assessed through audits (prevention action), and among possible corrections there might be choosing another supplier or making the supplier aware of gluten contamination risks. Additional prevention actions might be inspection on delivery and control of documents (e.g., certificate of gluten analysis from the producer and/or other documentation by the supplier; documents identifying the cargo-product, GF nature, lot number, quantity, source, and destination) and random sampling according to an analytical plan. As a correction, raw materials might be refused or stored separately (identified as not-to-be-used) while awaiting documents from supplier and/or analysis result.

\subsubsection{Analytical Methods}

Analytical testing plays a pivotal role in risk allergen management: it helps and supports understanding of the system. In detail, it confirms the safety of raw materials; it validates allergen control measures, such as cleaning practices and segregation barriers; it confirms the status of any claim and provides quantitative data for the purpose of risk assessment.

There are currently several quantitative and qualitative methods that are available for gluten detection. It has nevertheless become quite important for all the stakeholders of gluten risk analysis to understand the advantages and limitations of the available analytical tools, so as to select, when possible, the most appropriate method to ensure that the analytical results provide meaningful data.

\section{Enzyme-Linked Immunosorbent Assays}

Enzyme-linked immunosorbent assays (ELISA) are based on detection antibodies, covalently linked to an enzyme (e.g., horseradish peroxidase or alkaline phosphatase) which generates a coloured, chemiluminescent or fluorescent product which is thus measured.

They use a specific antibody $(\mathrm{Ab})$ to detect the antigen (i.e., an immunoglobulin), or polyclonal antibodies (pAbs) which are a mixture of immunoglobulins reacting against a specific antigen and each binding to a different epitope. Several gluten- or gliadin-specific antibodies, targeting different fragments of gluten proteins, have been developed so far, and a huge number of ELISA kits for gluten detection are currently available on the market (Table 1 ). 
Quantitative ELISAs can be developed in the sandwich or competitive formats. The sandwich ELISA is the most common format used for detection of food allergens in general and specifically for gluten [21]. However, methods based on the sandwich version are not suitable for quantifying gluten in hydrolised samples, because the presence of protein fragments with more than one binding site is unlikely. On the contrary, competitive assays are more suitable to that aim, as the target does not require multiple epitopes to be quantified [22].

Table 1. List of commercial ELISA kits for gluten detection in foods.

\begin{tabular}{|c|c|c|c|c|c|}
\hline \multicolumn{2}{|c|}{ Antibody } & \multirow{2}{*}{ Commercial Name } & \multirow{2}{*}{ Format } & \multirow{2}{*}{ Manufacturer } & \multirow{2}{*}{ Validation/Certification } \\
\hline Name & Type & & & & \\
\hline \multirow{10}{*}{$\begin{array}{l}\text { Skerrit mAb } \\
\text { (also known as } \\
\text { mAb 401.21) }\end{array}$} & \multirow{10}{*}{$\mathrm{mAb}$} & $\begin{array}{l}\text { Gluten-Check } \\
\text { ELISA kit }\end{array}$ & Sandwich & $\begin{array}{l}\text { BipCheck } \\
\text { (UK) }\end{array}$ & \\
\hline & & Gliadin assay & Sandwich & $\begin{array}{c}\text { ELISA } \\
\text { Systems }\end{array}$ & \\
\hline & & $\begin{array}{l}\text { ALLER-TEK } \\
\text { Gluten ELISA }\end{array}$ & Sandwich & ELISA Tech. & $\begin{array}{c}\text { Certified as a Performance Tested } \\
\text { Method }^{\mathrm{SM}}(\# 081202) \text { by the AOAC } \\
\text { Research Institute }\end{array}$ \\
\hline & & EZ gluten ${ }^{\circledR}$ & LFD & ELISA Tech. & $\begin{array}{c}\text { Certified as a Performance Tested } \\
\text { Method }^{\mathrm{SM}} \text { (\#051101) by the AOAC } \\
\text { Research Institute }\end{array}$ \\
\hline & & $\begin{array}{l}\text { Gluten-Check } \\
\text { ELISA Kit }\end{array}$ & Sandwich & Imutest & - \\
\hline & & Gluten-in-Food Test & Screening test & Imutest & - \\
\hline & & Alert ${ }^{\circledR}$ for Gliadin & Screening test & Neogen & - \\
\hline & & $\begin{array}{l}\text { BioKits Gluten } \\
\text { Assay Kit }\end{array}$ & Sandwich & Neogen & - \\
\hline & & $\begin{array}{l}\text { Veratox }^{\circledR} \text { for } \\
\text { Gliadin }\end{array}$ & Sandwich & Neogen & - \\
\hline & & $\begin{array}{l}\text { Reveal 3-D for } \\
\text { Gluten }\end{array}$ & LFD & Neogen & - \\
\hline$\alpha-20$ & $\mathrm{mAb}$ & $\begin{array}{l}\text { Gluten-TEC }^{\circledR} \\
\text { ELISA }\end{array}$ & Competitive & Euro-Proxima & - \\
\hline \multirow{7}{*}{ G12 } & \multirow{7}{*}{$\mathrm{mAb}$} & $\begin{array}{l}\text { Gluten Tox ELISA } \\
\text { Sandwich }\end{array}$ & Sandwich & $\begin{array}{l}\text { Biomedal } \\
\text { Diagnostics }\end{array}$ & - \\
\hline & & $\begin{array}{l}\text { Gluten Tox ELISA } \\
\text { Competitive }\end{array}$ & Competitive & $\begin{array}{c}\text { Biomedal } \\
\text { Diagnostics }\end{array}$ & - \\
\hline & & $\begin{array}{c}\text { Gluten Tox ELISA } \\
\text { Sticks }\end{array}$ & LFD & $\begin{array}{l}\text { Biomedal } \\
\text { Diagnostics }\end{array}$ & - \\
\hline & & $\begin{array}{l}\text { AgraQuant }{ }^{\circledR} \text { ELISA } \\
\text { Gluten G12 }\end{array}$ & Sandwich & RomerLab & - \\
\hline & & AgraStrip ${ }^{\circledR}$ Gluten & LFD & RomerLab & - \\
\hline & & $\begin{array}{c}\text { AgraStrip }{ }^{\circledR} \text { Gluten } \\
\text { G12 }^{\mathrm{TM}}\end{array}$ & LFD & RomerLab & - \\
\hline & & $\begin{array}{l}\text { Proteon Gluten } \\
\text { Express }\end{array}$ & Dipstick & Zeulab & - \\
\hline
\end{tabular}


Table 1. Cont.

\begin{tabular}{|c|c|c|c|c|c|}
\hline \multicolumn{2}{|c|}{ Antibody } & \multirow{2}{*}{ Commercial Name } & \multirow{2}{*}{ Format } & \multirow{2}{*}{ Manufacturer } & \multirow{2}{*}{ Validation/Certification } \\
\hline Name & Type & & & & \\
\hline \multirow{10}{*}{$\mathrm{R} 5$} & \multirow{10}{*}{$\mathrm{mAb}$} & TransiaPlateProlamins & Sandwich & $\begin{array}{l}\text { Bio Control } \\
\text { Systems }\end{array}$ & - \\
\hline & & Ingezim Gluten ${ }^{\circledR}$ & Sandwich & Ingenasa & - \\
\hline & & Ingezim Gluten ${ }^{\circledR}$ SemiQ & Sandwich & Ingenasa & - \\
\hline & & $\begin{array}{l}\text { Ingezim Gluten }^{\circledR} \\
\text { Hidrolizado }\end{array}$ & Direct & Ingenasa & - \\
\hline & & Alert $^{\circledR}$ for Gliadin R5 & Screening test & Neogen & - \\
\hline & & Veratox ${ }^{\circledR}$ for Gliadin R5 & Sandwich & Neogen & - \\
\hline & & RIDASCREEN $^{\circledR}$ Gliadin & Sandwich & R-Biopharm & $\begin{array}{l}\text { AOAC-OMA } 2012.01 \\
\text { AOAC-RI } 120601 \\
\text { AACCI } 38.50 .01\end{array}$ \\
\hline & & $\begin{array}{l}\text { RIDASCREEN }^{\circledR} \text { Gliadin } \\
\text { Competitive }\end{array}$ & Competitive & R-Biopharm & $\begin{array}{c}\text { AACCI } 38.55 .01 \\
\text { AOAC-OMA 2015.05 }\end{array}$ \\
\hline & & $\begin{array}{l}\text { RIDASCREEN }^{\circledR} \text { FAST } \\
\text { Gliadin sensitive }\end{array}$ & Sandwich & R-Biopharm & Internal validation \\
\hline & & Rida ${ }^{\circledR}$ Quick Gliadin & LFD & R-Biopharm & $\begin{array}{c}\text { AACCI 38-60.01 } \\
\text { AOAC Official First Action Methods } \\
2015.16 \\
\text { AOAC-RI in process }\end{array}$ \\
\hline \multirow{9}{*}{$\mathrm{pAb}$} & \multirow{9}{*}{$\mathrm{pAb}$} & Gluten/Gliadin ELISA kit & Sandwich & Abnova & - \\
\hline & & Gluten ELISA kit & Competitive & AstoriTecnica & - \\
\hline & & $\begin{array}{c}\text { AccuDiag }^{\mathrm{TM}} \\
\text { Gliadin/Gluten ELISA }\end{array}$ & Sandwich & $\begin{array}{l}\text { Diagnostic } \\
\text { Automation }\end{array}$ & - \\
\hline & & Gluten Rapid Kit & LFD & $\begin{array}{l}\text { Elution } \\
\text { Technologies }\end{array}$ & - \\
\hline & & Gliadin/Gluten & Sandwich & Immunolab & - \\
\hline & & Gluten Alert ELISA & Competitive & InCura & - \\
\hline & & Wheat Protein ELISA Kit & Sandwich & $\begin{array}{l}\text { Morinaga } \\
\text { Institute }\end{array}$ & - \\
\hline & & $\begin{array}{l}\text { Agra Quant }{ }^{\circledR} \\
\text { ELISA Gluten }\end{array}$ & Sandwich & Romer Labs & $\begin{array}{c}\text { AOAC Official Method No. } 2014.03 \\
\text { AACC International Approved } \\
\text { method (AACCI 38-52.01) }\end{array}$ \\
\hline & & Agra Strip ${ }^{\circledR}$ LFD Gluten & LFD & Romer Labs & $\begin{array}{l}\text { Certification of the AOAC Research } \\
\text { Institute for Performance Tested } \\
\text { methods (Certificate No. 061403) }\end{array}$ \\
\hline
\end{tabular}

LFD = Lateral Flow Device; $\mathrm{mAb}=$ monoclonal antibody; $\mathrm{pAb}=$ polyclonal antibody.

Several ELISA kits for gluten detection are available on the market and they are mainly based on the Skerritt (also known as mAb 401.21), or R5, or G12 or $\alpha 20$ monoclonal antibodies (mAbs). The Skerrit $\mathrm{mAb}$ is raised against HMW-glutenins and $\omega$-gliadins [23]. The sister line $\mathrm{mAb} 412.01$ detects the epitope QQGYYP [23]. The anti $\omega$-gliadin Ab is used in a sandwich format and was approved as an official method (Official Method 991.19) by the Association of Official Analytical Chemists (AOAC) [24]. 
The $\mathrm{R} 5 \mathrm{mAb}$ is raised against $\omega$-secalins and most recognizes the epitope QQPFP and the related sequences QQQFP, LQPFP and QLPFP which occur repeatedly in all gliadins, hordeins and secalins. It shows limited reactivity towards glutenins [21-23]. AACC International adopted the sandwich R5 ELISA, together with cocktail extraction, as Approved Method 38-50.01 [25] after validation by two collaborative studies (Table 1) [26,27]. It is also endorsed by the AOACI as Official Method 2012.01 [24] and by the Codex Committee on Methods of Analysis and Sampling (CCMAS) as a type 1 method (Table 1) for the analysis of intact gluten in corn-based matrices [28]. The sandwich ELISA showed to be useful for detection of gluten in natural and heat-processed samples [29]. A competitive R5 ELISA was developed for the determination of partially hydrolysed gluten and accepted as AACCI Approved Method 38-55.01 [30] (Table 1).

Recently, an ELISA kit, based on the G12 mAb, has been accepted by AOAC as an Official First Action method [31]. The G12 mAb is raised against the CD-immunogenic 33-mer peptide of $\alpha 2$-gliadin and reacts with the QPQLPY epitope. It detects wheat, rye, and barley prolamins, but it has a low sensitivity against glutelins. Interestingly, with respect to other mAbs, the G12 mAb shows limited affinity to oats, and the reactivity is generally proportional to the potential immunotoxicity of the oat cultivar. It is nevertheless unsuitable for detecting wheat, rye or barley contaminations in oats [32-34].

The $\mathrm{A} 1 \mathrm{mAb}$ is also raised against the CD-immunogenic 33-mer peptide of $\alpha 2$-gliadin, and it reacts with the epitope QLPYPQP. The $\omega 20 \mathrm{mAb}$ is raised against the CD-immunogenic peptide PFRPQQPYPQP from $\alpha$-gliadins; it recognizes gliadins, secalins and hordeins, however, further investigations on reactivities is required [32-34].

A range of monoclonal antibodies against gluten-derived $\mathrm{T}$ cell immune-stimulatory epitopes involved in $C D$, including an antibody specific for the DQ2.5-glia- $\alpha 3$ epitope, has been identified and characterized [35]. Based on this antibody, a commercial test kit, with a performance comparable to the R5 sandwich ELISA, was developed (Table 1). The sensitive competitive assay detects the well-characterized T cell stimulatory DQ2.5-glia- $\alpha 3$ epitope and homologous sequences present in barley, rye and their crossbred varieties. Sajic and colleagues [36] have recently highlighted that the Gluten-Tec ${ }^{\circledR}$ ELISA developed by EuroProxima was not able to detect PWG gliadin reference material in spiked samples. They have thus worked at the improvement and validation of a new Gliadin ELISA which can detect as little as $0.01 \%$ wheat gluten and gluten-like proteins from rye and barley in oats. Moreover, it can be used for gluten detection in processed foodstuffs, such as sauces, soups and beers.

Röckendorf and colleagues [37] have recently identified new sequences of gliadins and glutenins from wheat which provoke the production of antibodies: QQQYPS in $\alpha$ - and $\beta$-gliadins; PQQSFP in $\gamma$-gliadins; QPGQGQQG in HMW-GS, and QPGQGQQG in LMW-GS, which might be exploitable for the development of new kits.

Polyclonal Abs are usually raised against gliadins, and the advantage on their use is that the analysis may be less influenced by variation of cereal species, cultivar, and modifications during processing. The limited supply of identical pAbs and their less extensive characterisation are, on the other hand, major disadvantages. Sharma and colleagues [38] have recently characterized polyclonal antibodies, raised against gluten-containing grain-specific peptides. As minimal or no cross-reactivity of the studied antibodies with gluten from grains other than wheat was observed, these pAbs might be used for the development of new test kits.

Immunosensors, Dipsticks and Lateral Flow Devices, Western Blot

As an alternative to ELISAs, immunosensors, dipsticks and lateral flow devices (LFDs) can be used. Immunosensors are analytical devices combining the biological component, that is, an antibody/antigen, and a physico-chemical transducer. This means that the interaction between the antibody and the antigen results in a signal, generated by the physico-chemical change, and fluorescent molecules/enzymes. Some immunosensors have been already developed [32] and promising results were obtained (i.e., a highly sensitive Limit Of Detection (LOD; $10 \mathrm{ng}$ gliadin/mL)). Moreover, 
they offer further advantages, as they are indeed user-friendly, cost-effective, rapid, miniaturized and useful for on-site analysis [32].

Among the latest experimental immunosensors, it is worth mentioning the immunosensor developed by Funari and colleagues [39]. By combining a cheap and robust piezoelectric transducer (quartz crystal microbalance technology) and the photonic immobilization technique, they managed to obtain a LOD of about $4 \mathrm{ppm}$ and a sensitivity of about 7.5-15 ppm. The device is also able to keep the influence of false positives low. A giant magnetoresistive (GMR) sensor array was developed by $\mathrm{Ng}$ and colleagues [40]; an electrochemical label-free immunosensor for ultrasensitive and specific detection of gliadin by Chekin and colleagues [41]; an electrochemical assay was developed by Eksin and colleagues [42] upon combination of differential pulse voltammetry and disposable pencil graphite electrode.

Biosensors detect gliadin contamination in GF food products with promising LOD [43-45], but they are not available on the market yet [46].

There are also immuno-chromatographic assays available in the format of dipsticks and LFDs. The principle is the presence of a line of fixed antibody on the surface of a strip, and the presence of a second antibody conjugated with coloured nano-sized particles. They are very good candidates, as they are relatively cheap to produce, easy to use, and rapid, as they do not require special instrumentation (such as the microplate reader and washer that are needed for quantitative ELISAs), and little training is needed to perform the analysis, and they assure qualitative results with an indication of gluten presence/absence. Most use the sandwich type methodology [43]. The qualitative R5 immuno-chromatographic dipstick for the determination of gluten in processed and non-processed corn products, developed within a collaborative study under the aegis of the AACC International (AACCI) Protein Technical Committee (now Protein and Enzymes Technical Committee) [47], is accepted by AOAC as Official First Action Method 2015.16 [24] (Table 1).

The dipsticks and LFD currently available on the market are based on the R5, G12 and Skerrit mAbs and on some pAbs. Immunological western blots are also used to tackle the low sensitivity of single and two-dimensional gel electrophoresis (both SDS-PAGE and A-PAGE). The R5, or G12, or anti cells T gliadin $\alpha-20$ antibodies are used.Non-Immunological Methods: Proteomic and Genomic Techniques

Although the quantitative analysis of prolamins is mostly based on immunological methods, complementary and alternative non-immunological techniques are also used, especially to detect gluten in complex foods, to confirm the results of the immunological methods, to validate methods and to avoid false negative or positive results [32,33].

Among proteomics-based methods, Reverse-Phase (RP-) or Gel-Permeation (GP-) HighPerformance Liquid Chromatography (HPLC) with UV detection and gel electrophoresis are mainly used to characterize cereal proteins with a higher proficiency in flours [32,33]. However, they are inadequate to trace gluten in complex food matrices because of the low selectivity and sensitivity.

Mass Spectrometry (MS) methods have a high sensitivity, and, in the modern proteomic approaches, they are coupled with different methods of ionization, separation and detection: Matrix-Assisted Laser Desorption/Ionization (MALDI), Electrospray Ionization (ESI), time-of-flight (TOF), ion trap or triple quadrupole detection [32].

MALDI-TOF MS was the first technique to be used to quantitate intact gluten proteins in food samples, instead of immunological assays. However, despite the several adjustments which have been made, such as a two-step extraction, it has shown an insufficient sensitivity, a low accuracy at high mass and suppression effects due to the complexity of the protein mixture. Because of that, MALDI-TOF MS is mainly used for semi-quantitative measurements [32]. The extensive sequence similarities among gluten proteins and gluten hydrolisation are also a problem.

A proteomic approach involving tandem mass spectrometry (MS/MS) may hence result more promising [33]. Over the last three years, interesting results have been obtained within studies who aimed at quantitating gluten marker peptides by liquid chromatography tandem mass spectrometry 
(LC-MS/MS) [48-51]. Schalk and colleagues [48] developed a novel strategy to define wheat marker peptides by an LC-MS/MS method for the quantitative determination of wheat marker peptides. The quantitation successfully enabled the conversion of peptide into protein concentrations and hence the quantitation of gluten concentration. The latter was also compared to data obtained by GP-HPLC with fluorescence detector and R5 ELISA and showed to be not significantly different. One shortcoming was observed only in case of samples with a low content of gluten $(<100 \mu \mathrm{g})$, as the new method showed a lower sensitivity. According to the authors, this shortcoming might be overcome by using a different MS instrument.

Generally speaking, in case of identification and quantitation of gluten peptides by (LC-MS/MS), the key points to consider are the use of an appropriate extraction of gluten proteins and peptides from the sample; the choice of a suitable enzyme (endo-proteasis) for gluten digestion; the selection of a specific gluten marker peptide; and the calibration with a suitable reference material for the final calculation of gluten content [32]. As to the choice of a suitable enzyme, trypsin is the most used enzyme: it cleaves C-terminal to lysine and arginine. However, in the case of gluten detection, the cleavage points are not suitable for the generation of peptides which are easily quantifiable by the proteomic techniques. To that aim, research is necessary to identify enzymes which allow to obtain more appropriate gluten fragments and whose digestion is more reproducible [34]. Moreover, the peptides must be unique to gluten proteins and must ionize efficiently and chromatograph in a stable and reproducible way.

The main drawback for proteomic techniques relies nevertheless on the fact that expensive equipment and operator expertise are required to obtain accurate results. Genomic techniques do not target gluten proteins, but DNA or RNA which are markers indicative of the presence of gluten. They have thus attracted great attention, on the basis of several advantages. DNA has a higher stability. DNA presents the advantage it is efficiently extracted also under harsh conditions and is not influenced by the extraction phase as proteins are. DNA analysis presents a higher sensitivity than proteins [32,33]. DNA fragments can be, in fact, amplified by polymerase chain reaction (PCR) generating thousands to millions of copies in a short time. In the case of processed foods, DNA also offers the advantage of being less subject to thermal and/or enzymatic transformations than proteins and is more stable. Genomic-based methods are thus considered a complement and/or confirmation of the protein-based methods, but somehow also a promising alternative [33].

Several PCR-based methods have been so far developed for the detection and quantification of DNA of gluten-containing cereals, though only a few of them have been applied [33]. Among the most recent studies, Dubois and colleagues [52] developed four TaqMan probes which specifically target the canonical form of the four major celiac disease epitopes of $\alpha$-gliadin, whose toxicity can be reduced or even suppressed according to the allelic form of each sequence. They also developed six TaqMan probes targeting stable reference genes and used them to measure the epitope expression levels of 11 contrasted spelt accessions and three ancestral diploid accessions of bread wheat and spelt.

\section{Discussion}

\subsection{Challenges in Gluten Risk Management}

\subsubsection{The Legislative Framework}

The specific meaning of the "gluten-free" and "low in gluten" claims differs throughout the world legislative framework. At the moment, four different thresholds can be distinguished. As to the "gluten-free" claim, Australia and New Zealand establish a $<3$ ppm gluten value, whereas in Europe and USA a threshold of $<20 \mathrm{ppm}$ is laid down. A "very low in gluten" food product has in Europe a $<100$ ppm gluten content. Australia and New Zealand have established only a "low in gluten" claim identifying products with a gluten content of $<200$ ppm gluten.

This implies that a same product can have different claims, depending on the country it is brought on the market. Subsequently, it might mislead CD patients, when actually the bottom line in GF 
product safety is that labels allow patients suffering from gluten-related disorders to make safer food choices.

It is hence advisable to have as soon as possible quantitative legislative guidance and harmonized safety thresholds, so as to guarantee a not misleading labelling action.

\subsubsection{Estimation of Gluten Exposure and Health Impact Thereof on Coeliac Patients}

Gluten risk management should also take into consideration the exposure of coeliac patients to gluten. Establishing a threshold value for GF product labelling might be not safe enough for coeliacs, as the exposure depends on the amount of gluten present in food products and on the amount of product consumed.

Moreover, the assessment of gluten exposure would be necessary to set the amount of gluten tolerated by subjects suffering from CD. However, the identification of a single gluten-safe threshold for the population suffering from $\mathrm{CD}$ is rather complicated. On the one hand, sensitivity to gluten differs from person to person. It seems that a combination of gender, physical activity, weight, age and other factors all play a part [53]. On the other hand, the estimation of gluten content differs from method to method. Hence, the exposure to gluten could be over- or under-estimated.

New epidemiological studies might contribute to obtain reliable data about gluten exposure, provided that gluten is detected by the same method.

\subsubsection{Main Requirements and Challenges of Currently Available Methods for Gluten Tracing}

Immunological assays are well-accepted methods to track allergen contamination. They have advantages in terms of being commercially available in the format of test kits, at relatively low cost, and being a fast and easy-to-use analytical tool. However, inconsistency in the measurement results obtained by the different ELISA kits available in commerce was observed.

Results vary from kit to kit and measurements are not comparable [26,27]. Rzychon and colleagues [54] reported on the large discrepancies among kits, with a $46-124 \%$ range for the reproducibility. A qualitative response model revealed, in fact, a $50 \%$ probability that a food deemed having a gluten content lower than $20 \mathrm{ppm}$, on the basis of measurements performed by available ELISA test kits, contains up to $80-90$ ppm of gluten. As to the "low gluten" claim, it emerged a 50\% probability that the real gluten content were $>100 \mathrm{ppm}$, with a peak of 210-220 ppm [54].

Results obtained with ELISA kits are, in fact, influenced by some factors, such as the type of the applied antibody, gluten extraction procedures and lack of reference material.

Proteomic and genomic methods have some advantages in terms of accurate gluten quantitation, but they require expensive equipment and trained operators. This prevents them from being used in routine tests.

Type of Antibody in Immunological Assays

The majority of the official methods validated by AOAC or AACCI are based on the R5 $\mathrm{mAb}$, which has generally shown some advantages compared to the other antibodies. R5 is less cultivar-dependent than other antibodies [29]. On the contrary, the Skerrit mAb is raised against $\omega$-gliadins whose content is strongly dependent on wheat cultivar [29,32].

The epitope, which R5 is raised against (i.e., QQPFP and related sequences), is widely distributed in all sub-fractions of gliadins. It can thus be used to measure gluten in cooked foods, as long as heat treatment leaves the QQPFP epitope unchanged. Moreover, the antibody allows the measurement of the motifs on $\alpha$ - and $\gamma$-gliadins [29]. Results are hence not affected by the high variation in the ratio between $\omega$-gliadin and total gliadins.

The high sensitivity of ELISAs based on the R5 antibody also allows for monitoring gluten levels as low as $2.5 \mathrm{ppm}$ in commercial GF foods, raw products, wheat starches, and contaminated oat- or buckwheat-based foods [29]. In contrast, the ELISAs based on the Skerrit mAb have shown a Limit of Quantitation (LOQ) of $5 \mathrm{mg}$ gluten $/ \mathrm{kg}$ [32]. 
The R5 antibody reacts with rye and barley, whereas no cross reactivity to oats is observed, since the QQPFP epitope is not found in oat avenins. Despite some authors claimed positive cross-reactivity of R5 with soy proteins, Lacorn and colleagues [55] have recently highlighted that no false-positive results are actually obtained with R5-based gluten ELISA kits, provided that skim-milk powder is added if the sample is extracted with $60 \%$ ethanol.

Despite these advantages, the sandwich format of ELISA kits based on R5 can be used only for detection of non-hydrolyzed gluten, as it requires the presence of at least two epitopes in a protein or peptide. In case smaller gliadin fragments, containing only one epitope, formed upon food processing, the quantification would be no longer accurate. For this reason, a competitive ELISA approach is required to analyze processed food. However, one of the major problems in developing a competitive ELISA for the quantification of hydrolyzed gliadins is to identify the right standard.

Röckendorf and colleagues [37] also observed that although R5 is a better performer than G12 and $\alpha 20$ in the detection of selected CD-active gluten fractions, it has nevertheless some limitations, as two thirds of fragments investigated in their study remained undetected.

Other research groups have recently compared the performance of the different antibodies [56-59] on several food matrices, from grains of different species (e.g., wheat, rye and barley) to fermented-hydrolyzed foods.

\section{Gluten Extraction Procedure in Immunological Assays}

It is a shared position within the scientific community that the identification of the most suitable sample preparation and extraction procedure is one more critical point in gluten determination $[32,33,59]$. It is known that the main requirement for immunological assays is, in fact, that they should be able to measure the toxic proteins, regardless of the type of food (raw material or heat-treated and enzymatically-treated product). The solvent most commonly used to extract the prolamins fraction from raw materials, such as flours, is aqueous alcohol, namely, $60 \%$ ethanol or $50 \%$ propanol $[32,33,59]$. Partially hydrolised gluten is soluble in aqueous alcohol solutions and also in water or salt solutions. Native gluten proteins are insoluble in water or salt solution due to inter- and intra-molecular disulphide bonds. Moreover, they have a limited stability when solubilised.

In heat-processed foods like bread, extruded products like pasta, or products containing hydrolysed gluten, proteins are degraded and hydrolyzed, or protein aggregates may form. This means that the aqueous alcohol solution is inadequate and the food toxicity can be underestimated [32,33,59]. To counteract these critical points, when gluten detection is made on thermally processed samples, additional agents (disaggregating and reducing) are used to break the interchain S-S- bonds of proteins and solubilise gluten. Guanidine chloride and $\beta$-mercaptoethanol are used. The extraction solution is known as "cocktail", and it is recognized by the Codex Alimentarius Commission as the extraction procedure of choice for the sandwich R5 ELISA, guaranteeing a LOQ of $1.56 \mathrm{ppm}$ of gliadins [33]. The critical point with the cocktail solution is the safety for the chemical technician performing the analysis: guanidine hydrochloride is corrosive, and 2-mercaptoethanol has disagreeable odour, is harmful by inhalation, toxic volatile, and hazardous for the environment as well. Moreover, no certified reference material is available. Some immunoassays, especially in the competitive format, are also incompatible with this extraction solution, as its components can denature the protein receptor [33].

So far, alternative solutions have been used, such as the Universal Prolamin and Glutelin Extractant Solution (UPEX), containing the odourless reducing agent Tris(2-carboxyethyl)-phosphine (TCEP) and the reducing agent $N$-lauroylsarcosine [59]. UPEX has shown to be compatible with immunochemical methods and be able to improve the extraction of both native and denaturated gluten proteins, as the TCPE breaks the disulphide bridges and the N-lauroylsarcosine contributes to open polypeptide chains more than guanidine chloride can do [33].

In addition, in case of a food product with a high fat content $(>10 \%)$, an additional step of defatting with n-hexane is required; in case of foods rich in polyphenols, skim milk powder, or fish 
gelatine and/or polyvinylpyrrolidone are to be added to the extraction solution to disrupt gluten protein-polyphenol interactions. According to Scherf and Poms [32], the compatibility of the extraction solvent with the analytical procedure used is to be verified for each procedure.

Reference Material in Immunological Assays

The lack of reference material (RM) is also claimed, and the possibility of having it available is perceived as a likely solution to the current issue of gluten quantification [59]. The most used material for calibration and validation is the PWG, that is, a highly purified gliadin obtained from a mixture of 28 European wheat cultivars prepared by the Working Group on Prolamin Analysis and Toxicity. The PWG is indeed a homogenous and stable material; it guarantees a high degree of repeatability, reproducibility and stability. However, it only represents the prolamins fraction of some cereals, when actually cereals contain a greater number of proteins.

According to Rosell and colleagues the PWG is however not suitable for gluten detection in fermented wheat-, rye- and barley-based food products, they hence speculate about the possibility of using a hydrolyzed standard combined with a competitive assay [33]. Mena and colleagues [59] stated that the PWG gliadin standard is a more accessible standard, and is to be considered of choice with respect to a partially enzymatically digested gliadin standard which can be difficult to prepare in terms of reproducibility.

Very recently, Hajas and colleagues [60] have worked at the identification of one or more cultivars that would be suitable for the production of RM. To that aim, they have characterized a set of 23 common bread wheat cultivars, grown worldwide and selected on the basis of qualitative and quantitative criteria, by various methods (e.g., SE-HPLC, RP-HPLC, SDS-PAGE and ELISA). They however concluded that further studies are required to understand if a single cultivar or a mixture of selected cultivars should be used for the production of RM. The question whether RM should be based only on a single protein fraction or reference flour remains unanswered as well.

\section{Challenges in Proteomic and Genomic Techniques}

Regarding proteomic techniques, one of the major hurdles limiting the use of these methods is the lack of comprehensive and well annotated sequence databases for gluten. Bromilow and colleagues [61] have developed an open-source wheat gluten protein sequence database (GluPro V1.0) in a FASTA format to support the application of proteomic methods for gluten protein detection and quantification. The database comprises 630 discrete unique full-length protein sequences and represents the different types of gliadin and glutenin components found in gluten. The researchers observed that more reliable identifications can be obtained using the GluPro V1.0 database. This thus highlights the importance of relying on a sequence database specifically designed. Provision of this tool would thus support the proteomic workflows and improve the reliability of gluten protein identification by proteomic analysis; it would also aid the development of targeted mass spectrometry methods to detect and quantify gluten in line with Codex Alimentarius Commission requirements for foods designed to meet the needs of gluten intolerant individuals.

Among genomic techniques, quantitative real-time PCR (Q-PCR) based on the fluorescent dye SYBR Green I, was not appropriate for highly processed foods, as it cannot identify hydrolysed DNA. In addition, it is unsuitable to establish a correlation between the found DNA and gluten content.

\section{Conclusions}

Analytical methods play a pivotal role in risk assessment and risk management plans, as they can provide food companies with data on allergen concentrations along the production chain.

However, challenges remain along the way and efforts are required to overcome the aforesaid drawbacks. At the moment, ELISAs are the methods of choice for gluten detection, despite the type of antibody, the sample preparation and the lack of reference material can impair analytical results. Proteomics-based methods can be an alternative, in terms of accurate quantitation of gluten, but the 
expensive equipment and the expertise they require prevent them from being used in routine analysis. The recent provision of a wheat gluten protein sequence database is likely to aid the development of targeted mass spectrometry methods to detect and quantify gluten in line with Codex Alimentarius Commission requirements.

As the currently on-force worldwide legislation sets "gluten-free" and "low in gluten" claims, reliable data about gluten content are necessary for GF food labelling. Threshold values for gluten content in packaged and processed foods should also be harmonised, so as to assist consumers in making safe food choices worldwide.

Author Contributions: Authors equally contributed to the design, preparation and revision of the manuscript.

Funding: This research received no external funding.

Conflicts of Interest: The authors declare no conflict of interest.

\section{References}

1. Sicherer, S.H.; Sampson, H.A. Food allergy. J. Allergy Clin. Immunol. 2010, 125, S116-S125. [CrossRef] [PubMed]

2. European Academy of Allergy and Clinical Immunology Advocacy Manifesto-Tackling the Allergy Crisis in Europe. Available online: http:/ /www.eaaci.org/outreach/public-declarations/3243-advocacy-manifestotackling-the-allergy-crisis-in-europe,-2015.html (accessed on 8 October 2018).

3. European Union. Regulation (EU) No 1169/2011 of the European Parliament and of the Council of 25 October 2011 on the Provision of Food Information to Consumers, Amending Regulations (EC) No 1924/2006 and (EC) No 1925/2006 of the European Parliament and of the Council, and Repealing Commission Directive 87/250/EEC, Council Directive 90/496/EEC, Commission Directive 1999/10/EC, Directive 2000/13/EC of the European Parliament and of the Council, Commission Directives 2002/67/EC and 2008/5/EC and Commission Regulation (EC) No 608/2004; European Union: Brussels, Belgium, 2011.

4. Leonard, M.M.; Sapone, A.; Catassi, C.; Fasano, A. Celiac Disease and Nonceliac Gluten Sensitivity: A Review. JAMA 2017, 318, 647-656. [CrossRef] [PubMed]

5. Lionetti, E.; Gatti, S.; Pulvirenti, A.; Catassi, C. Celiac disease from a global perspective. Best Pract. Res. Clin. Gastroenterol. 2015, 29, 365-379. [CrossRef] [PubMed]

6. Bustamante, M.Á.; Fernández-Gil, M.P.; Churruca, I.; Miranda, J.; Lasa, A.; Navarro, V.; Simón, E. Evolution of gluten content in cereal-based gluten-free products: An overview from 1998 to 2016. Nutrients 2017, 9. [CrossRef] [PubMed]

7. Verma, A.K.; Gatti, S.; Galeazzi, T.; Monachesi, C.; Padella, L.; Del Baldo, G.; Annibali, R.; Lionetti, E.; Catassi, C. Gluten contamination in naturally or labeled gluten-free products marketed in Italy. Nutrients 2017, 9. [CrossRef] [PubMed]

8. Farage, P.; De Medeiros Nóbrega, Y.K.; Pratesi, R.; Gandolfi, L.; Assunção, P.; Zandonadi, R.P. Gluten contamination in gluten-free bakery products: A risk for coeliac disease patients. Public Health Nutr. 2017, 20, 413-416. [CrossRef] [PubMed]

9. Standards CODEXALIMENTARIUS FAO-WHO. Available online: http://www.fao.org/fao-whocodexalimentarius/codex-texts/list-standards/en (accessed on 9 October 2018).

10. EU Law-EUR-Lex. Available online: https://eur-lex.europa.eu/homepage.html (accessed on 9 October 2018).

11. US Food and Drug Administration Home Page. Available online: https://www.fda.gov/ (accessed on 9 October 2018).

12. Government of Canada. Health Canada. Available online: https://www.canada.ca/en/health-canada.html (accessed on 9 October 2018).

13. Food Standards Australia New Zealand. Available online: http://www.foodstandards.gov.au/Pages/ default.aspx (accessed on 9 October 2018).

14. Galli, G.; Esposito, G.; Lahner, E.; Pilozzi, E.; Corleto, V.D.; Di Giulio, E.; Aloe Spiriti, M.A.; Annibale, B. Histological recovery and gluten-free diet adherence: A prospective 1-year follow-up study of adult patients with coeliac disease. Aliment. Pharmacol. Therapeut. 2014, 40, 639-647. [CrossRef] [PubMed] 
15. Garnier-Lengliné, H.; Cerf-Bensussan, N.; Ruemmele, F.M. Celiac disease in children. Clin. Res. Hepatol. Gastroenterol. 2015, 39, 544-551. [CrossRef] [PubMed]

16. European Union. Commission Regulation (EC) No 41/2009 of 20 January 2009 Concerning the Composition and Labelling of Foodstuffs Suitable for People Intolerant to Gluten (Text with EEA Relevance); European Union: Brussels, Belgium, 2009; pp. 3-5.

17. European Union. Regulation (EU) No 609/2013 of the European Parliament and of the Council of 12 June 2013 on Food Intended for Infants and Young Children, Food for Special Medical Purposes, and Total Diet Replacement for Weight Control and Repealing Council Directive 92/52/EEC, Commission Directives 96/8/EC, 1999/21/EC, 2006/125/EC and 2006/141/EC, Directive 2009/39/EC of the European Parliament and of the Council and Commission Regulations (EC) No 41/2009 and (EC) No 953/2009 Text with EEA Relevance; European Union: Brussels, Belgium, 2013; pp. 35-56.

18. European Union. Commission Implementing Regulation (EU) No 828/2014 of 30 July 2014 on the Requirements for the Provision of Information to Consumers on the Absence or Reduced Presence of Gluten in Food Text with EEA Relevance; European Union: Brussels, Belgium, 2014; pp. 5-8.

19. Government of Canada, Canadian Food Inspection Agency (CFIA). Compliance and Enforcement of Gluten-Free Claims. Available online: http:/ / www.inspection.gc.ca/food/labelling/food-labelling-forindustry/allergens-and-gluten/gluten-free-claims/eng/1340194596012/1340194681961 (accessed on 9 October 2018).

20. AOECS Gluten Free Standard Association of European Coeliac Societies (AOECS). Available online: https: / / www.aoecs.org/aoecs-gluten-free-standard (accessed on 9 October 2018).

21. Baumert, J.L. Detecting and Measuring Allergens in Food. Risk Manag. Food Allergy 2013, 215-226. [CrossRef]

22. Miranda-Castro, R.; de-los-Santos-Álvarez, N.; Miranda-Ordieres, A.J.; Lobo-Castañón, M.J. Harnessing Aptamers to Overcome Challenges in Gluten Detection. Biosensors (Basel) 2016, 6. [CrossRef] [PubMed]

23. Skerritt, J.H.; Hill, A.S.; Andrews, J.L. Antigenicity of Wheat Prolamins: Detailed Epitope Analysis using a Panel of Monoclonal Antibodies. J. Cereal Sci. 2000, 32, 259-279. [CrossRef]

24. AOAC. Official Methods of Analysis. Available online: http://www.aoac.org/AOAC_Prod_ Imis/AOAC_Member/Pubs/OMA/AOAC_Official_Methods_of_Analysis.aspx?WebsiteKey= 2e25ab5a-1f6d-4d78-a498-19b9763d11b4\&hkey=5142c478-ab50-4856-8939-a7a491756f48\&New_ ContentCollectionOrganizerCommon=3\#New_ContentCollectionOrganizerCommon (accessed on 6 November 2018).

25. AACC International Approved Methods-AACC Method 38-50.01. Gluten in Corn Flour and Corn-Based Products by Sandwich ELISA Available online: Available online: http://methods.aaccnet.org/summaries/3850-01.aspx (accessed on 6 November 2018).

26. Koehler, P.; Schwalb, T.; Immer, U.; Lacorn, M.; Wehling, P.; Don, C. AACCI approved methods technical committee report: Collaborative study on the immunochemical determination of intact gluten using an R5 sandwich ELISA. Cereal Foods World 2013, 58, 36-40. [CrossRef]

27. Méndez, E.; Vela, C.; Immer, U.; Janssen, F.W. Report of a collaborative trial to investigate the performance of the R5 enzyme linked immunoassay to determine gliadin in gluten-free food. Eur. J. Gastroenterol. Hepatol. 2005, 17, 1053-1063. [CrossRef] [PubMed]

28. Codex Committee. Report of the 27th Session of the Codex Committee on Methods of Analysis and Sampling, Budapest, Hungary, 15-19 May 2006; Codex Committee: Roma, Italy, 2006; p. 8.

29. Immer, U.; Haas-Lauterbach, S. Detection of Gluten and Related Proteins in Foods and Beverages and Safety Issues Related to Gluten Free Foods-Specific Detection with the R5 Antibody in a Ready-To-Use Test Kit for Industry. In The Science of Gluten-Free Foods and Beverages; Arendt, E.K., Bello, F.D., Eds.; American Associate of Cereal Chemists International; AACC International Press: St. Paul, MN, USA, 2009; pp. 41-52, ISBN 978-1-891127-67-0.

30. AACC International Approved Methods-AACC Method 38-55.01. Gluten in Fermented Cereal-Based Products by Competitive ELISA. Available online: http://methods.aaccnet.org/summaries/38-55-01.aspx (accessed on 6 November 2018).

31. Halbmayr-Jech, E.; Rogers, A.; Don, C.; Prinster, M. Gluten in Rice Flour and Baked Rice Products by G12 Sandwich ELISA: First Action 2014.03. J. AOAC Int. 2015, 98, 103-111. [CrossRef] [PubMed]

32. Scherf, K.A.; Poms, R.E. Recent developments in analytical methods for tracing gluten. J. Cereal Sci. 2016, 67, 112-122. [CrossRef] 
33. Rosell, C.M.; Barro, F.; Sousa, C.; Mena, M.C. Cereals for developing gluten-free products and analytical tools for gluten detection. J. Cereal Sci. 2014, 59, 354-364. [CrossRef]

34. Simón, E.; Lamelas, I.L.; Churruca, I.; Lasa, A.; Bustamante, M.Á.; Navarro, V.; Gil, M.; del, P.F.; Miranda, J. Nutritional and Analytical Approaches of Gluten-Free Diet in Celiac Disease; Springer International Publishing: Berlin, Germany, 2017; ISBN 978-3-319-53341-4.

35. Mitea, C.; Kooy-Winkelaar, Y.; van Veelen, P.; de Ru, A.; Drijfhout, J.W.; Koning, F.; Dekking, L. Fine specificity of monoclonal antibodies against celiac disease-inducing peptides in the gluteome. Am. J. Clin. Nutr. 2008, 88, 1057-1066. [CrossRef] [PubMed]

36. Sajic, N.; Oplatowska-Stachowiak, M.; Streppel, L.; Drijfhout, J.-W.; Salden, M.; Koning, F. Development and in-house validation of a competitive ELISA for the quantitative detection of gluten in food. Food Control 2017, 80, 401-410. [CrossRef]

37. Röckendorf, N.; Meckelein, B.; Scherf, K.A.; Schalk, K.; Koehler, P.; Frey, A. Identification of novel antibody-reactive detection sites for comprehensive gluten monitoring. PLoS ONE 2017, 12. [CrossRef] [PubMed]

38. Sharma, G.M.; Rallabhandi, P.; Williams, K.M.; Pahlavan, A. Characterization of Antibodies for Grain-Specific Gluten Detection. J. Food Sci. 2016, 81, T810-T816. [CrossRef] [PubMed]

39. Funari, R.; Terracciano, I.; Della Ventura, B.; Ricci, S.; Cardi, T.; D’Agostino, N.; Velotta, R. Label-Free Detection of Gliadin in Food by Quartz Crystal Microbalance-Based Immunosensor. J. Agric. Food Chem. 2017, 65, 1281-1289. [CrossRef] [PubMed]

40. Ng, E.; Nadeau, K.C.; Wang, S.X. Giant magnetoresistive sensor array for sensitive and specific multiplexed food allergen detection. Biosens. Bioelectron. 2016, 80, 359-365. [CrossRef] [PubMed]

41. Chekin, F.; Singh, S.K.; Vasilescu, A.; Dhavale, V.M.; Kurungot, S.; Boukherroub, R.; Szunerits, S. Reduced Graphene Oxide Modified Electrodes for Sensitive Sensing of Gliadin in Food Samples. ACS Sens. 2016, 1, 1462-1470. [CrossRef]

42. Eksin, E.; Congur, G.; Erdem, A. Electrochemical assay for determination of gluten in flour samples. Food Chem. 2015, 184, 183-187. [CrossRef] [PubMed]

43. Mena, M.C.; Sousa, C. Analytical Tools for Gluten Detection: Policies and Regulation. OmniaSci. Monogr. 2015. [CrossRef]

44. Neethirajan, S.; Weng, X.; Tah, A.; Cordero, J.O.; Ragavan, K.V. Nano-biosensor platforms for detecting food allergens-New trends. Sens. Bio-Sens. Res. 2018, 18, 13-30. [CrossRef]

45. Weng, X.; Gaur, G.; Neethirajan, S. Rapid Detection of Food Allergens by Microfluidics ELISA-Based Optical Sensor. Biosensors (Basel) 2016, 6, 24. [CrossRef] [PubMed]

46. Mena, M.C.; Lombardía, M.; Hernando, A.; Méndez, E.; Albar, J.P. Comprehensive analysis of gluten in processed foods using a new extraction method and a competitive ELISA based on the R5 antibody. Talanta 2012, 91, 33-40. [CrossRef] [PubMed]

47. Lacorn, M.; Weiss, T.; Uhlig, S.; Scherf, K. Determination of Gluten in Processed and Nonprocessed Corn Products by Qualitative R5 Immunochromatographic Dipstick: Collaborative Study, First Action 2015.16. J. AOAC Int. 2016. [CrossRef] [PubMed]

48. Schalk, K.; Koehler, P.; Scherf, K.A. Targeted liquid chromatography tandem mass spectrometry to quantitate wheat gluten using well-defined reference proteins. PLoS ONE 2018, 13, e0192804. [CrossRef] [PubMed]

49. Colgrave, M.L.; Goswami, H.; Byrne, K.; Blundell, M.; Howitt, C.A.; Tanner, G.J. Proteomic profiling of 16 cereal grains and the application of targeted proteomics to detect wheat contamination. J. Proteome Res. 2015, 14, 2659-2668. [CrossRef] [PubMed]

50. Van den Broeck, H.C.; Cordewener, J.H.G.; Nessen, M.A.; America, A.H.P.; van der Meer, I.M. Label free targeted detection and quantification of celiac disease immunogenic epitopes by mass spectrometry. J. Chromatogr. A 2015, 1391, 60-71. [CrossRef] [PubMed]

51. Manfredi, A.; Mattarozzi, M.; Giannetto, M.; Careri, M. Multiplex liquid chromatography-tandem mass spectrometry for the detection of wheat, oat, barley and rye prolamins towards the assessment of gluten-free product safety. Anal. Chim. Acta 2015, 895, 62-70. [CrossRef] [PubMed]

52. Dubois, B.; Bertin, P.; Muhovski, Y.; Escarnot, E.; Mingeot, D. Development of TaqMan probes targeting the four major celiac disease epitopes found in $\alpha$-gliadin sequences of spelt (Triticum aestivum ssp. spelta) and bread wheat (Triticum aestivum ssp. aestivum). Plant Methods 2017, 13, 72. [CrossRef] [PubMed] 
53. Bruins Slot, I.D.; Bremer, M.G.E.G.; Hamer, R.J.; van der Fels-Klerx, H.J. Part of celiac population still at risk despite current gluten thresholds. Trends Food Sci. Technol. 2015, 43, 219-226. [CrossRef]

54. Rzychon, M.; Brohée, M.; Cordeiro, F.; Haraszi, R.; Ulberth, F.; O'Connor, G. The feasibility of harmonizing gluten ELISA measurements. Food Chem. 2017, 234, 144-154. [CrossRef] [PubMed]

55. Lacorn, M.; Lindeke, S.; Siebeneicher, S.; Weiss, T. Commercial ELISA measurement of allergens and gluten: What we can learn from case studies. J. AOAC Int. 2018, 101, 102-107. [CrossRef] [PubMed]

56. Panda, R.; Boyer, M.; Garber, E.A.E. A multiplex competitive ELISA for the detection and characterization of gluten in fermented-hydrolyzed foods. Anal. Bioanal. Chem. 2017, 409, 6959-6973. [CrossRef] [PubMed]

57. Panda, R.; Zoerb, H.F.; Cho, C.Y.; Jackson, L.S.; Garber, E.A.E. Detection and Quantification of Gluten during the Brewing and Fermentation of Beer Using Antibody-Based Technologies. J. Food Prot. 2015, 78, 1167-1177. [CrossRef] [PubMed]

58. Lexhaller, B.; Tompos, C.; Scherf, K.A. Fundamental study on reactivities of gluten protein types from wheat, rye and barley with five sandwich ELISA test kits. Food Chem. 2017, 237, 320-330. [CrossRef] [PubMed]

59. Hochegger, R.; Mayer, W.; Prochaska, M. Comparison of R5 and G12 Antibody-Based ELISA Used for the Determination of the Gluten Content in Official Food Samples. Foods 2015, 4, 654-664. [CrossRef] [PubMed]

60. Hajas, L.; Scherf, K.A.; Török, K.; Bugyi, Z.; Schall, E.; Poms, R.E.; Koehler, P.; Tömösközi, S. Variation in protein composition among wheat (Triticum aestivum L.) cultivars to identify cultivars suitable as reference material for wheat gluten analysis. Food Chem. 2018, 267, 387-394. [CrossRef] [PubMed]

61. Bromilow, S.; Gethings, L.A.; Buckley, M.; Bromley, M.; Shewry, P.R.; Langridge, J.I.; Clare Mills, E.N. A curated gluten protein sequence database to support development of proteomics methods for determination of gluten in gluten-free foods. J. Proteom. 2017, 163, 67-75. [CrossRef] [PubMed]

(C) 2018 by the authors. Licensee MDPI, Basel, Switzerland. This article is an open access article distributed under the terms and conditions of the Creative Commons Attribution (CC BY) license (http:/ / creativecommons.org/licenses/by/4.0/). 